\section{Pacific Northwest}

National Laboratory

Operated by Battelle for the

U.S. Department of Energy

\title{
Test Summary Report INEEL Sodium-Bearing Waste Vitrification Demonstration RSM-01-2
}

\author{
RW Goles* \\ JA Del Debbio** \\ RJ Kirkham** \\ BD MacIsaac* \\ JA McCray** \\ DD Siemer** \\ NR Soelberg** \\ *Pacific Northwest National Laboratory \\ **Idaho National Engineering and Environmental Laboratory
}

May 2002

Prepared for the U.S. Department of Energy

under Contract DE-AC06-76RL01830 


\title{
Test Summary Report INEEL Sodium-Bearing Waste Vitrification Demonstration RSM-01-1
}

\author{
R. W. Goles* \\ J.A. Del Debbio** \\ R.J. Kirkham** \\ B.D. MacIsaac* \\ J. A. McCray** \\ D. D. Siemer** \\ N.R. Soelberg** \\ *Pacific Northwest National Laboratory \\ **Idaho National Engineering and Environmental Laboratory
}

May 2002

Prepared for the U.S. Department of Energy

under Contract DE-AC06-76RL01830

Pacific Northwest National Laboratory

Richland, Washington 99352 


\begin{abstract}
A research-scale, liquid-fed, ceramic-melter was used to conduct a flowsheet evaluation of a nonradioactive surrogate of sodium-bearing waste currently being stored in underground tanks at the Department of Energy's Idaho National Engineering and Environmental Laboratory. During this 120-h melter test, the processing characteristics of a glass formulated to have a high sulfur capacity were evaluated with and without reductant (sucrose or glycolic acid) additives. Beyond processing rates, this integrated melter/off-gas system demonstration test evaluated the impacts of reductant type (if used) and concentration upon 1) the partitioning of volatile (sulfur, mercury, and the halogens) and nonvolatile effluents, 2) the oxidation state of the melter glass, 3) the reduction of waste constituent nitrate, 4) the composition of secondary waste streams, and 5) the durability of the melter's glass product.
\end{abstract}




\section{Summary}

Over several decades, site operations, at what is now the U.S. Department of Energy's (DOE's) Idaho National Engineering and Environmental Laboratory (INEEL), have included nuclear reactor testing, reprocessing of spent nuclear fuel, and the storage, treatment, and disposal of the resultant radioactive and mixed wastes generated. Liquid, acidic, and radioactive high-level waste (HLW) and sodium bearing waste (SBW) from spent-fuel reprocessing operations have for the most part been calcined in the New Waste Calcining Facility (NWCF) and the earlier Waste Calcining Facility (WCF) to produce a dry granular waste form that is safer than liquid waste to store. However, about a million gallons of SBW remains uncalcined, and this liquid mixed waste, stored in tanks, does not meet current regulatory requirements for long-term storage and/or disposal. As a part of the Settlement Agreement between DOE and the State of Idaho, the tanks currently containing SBW are to be taken out of service by December 31, 2012, which requires the removal and treatment of the remaining SBW.

Several potential options have been proposed for treating the SBW. Of those considered, vitrification received the highest weighted score against the criteria used. Beginning in Fiscal Year 2000, the INEEL HLW program embarked on a program for technology demonstration and development that would lead to the conceptual design of a vitrification facility, based upon the liquid-fed melter technology, in the event that vitrification is the preferred alternative for SBW disposal. This program consists of several separate activities that include, among others, waste-form development, process feed-stream design, and melter vitrification demonstration testing of the nonradioactive, surrogate SBW flowsheet. The second of two FY 2001 melter flowsheet tests conducted at Pacific Northwest National Laboratory (PNNL) in support of INEEL's vitrification facility design is discussed below.

PNNL's Research-Scale Melter (RSM) was used to conduct these initial melter-flowsheet evaluations. The RSM is a small (1/100-scale, Defense Waste Processing Facility basis) joule-heated melter that is capable of processing melter feed on a continuous basis. This capability is key for:

- developing/evaluating process flowsheets

- characterizing relationships between feed composition and the properties of the final glass produced

- establishing the fate and behavior of process effluent.

This melter system's capability to produce glass in a continuous manner is also essential for estimating the behavior of a full-scale system. Moreover, the size of the RSM allows the impacts of process variables upon melter performance or glass quality to be quickly and efficiently evaluated without undue expense or waste generation.

The experimental scope of this initial, 5-d, 120-h, SBW vitrification test was to evaluate the:

- processing characteristics of the newly formulated SBW-22 surrogate melter feed formulation with and without reductant (sucrose or glycolic acid) additives

- effectiveness of SBW-22 glass to incorporate waste-stream sulfur

- suitability of using sugar or glycolic acid as glass oxidation-state modifiers and nitrate reductants 
- emission characteristics of the melter with a special emphasis on volatile effluents such as mercury, sulfur, and the halogens

- impact of flowsheet reductants upon secondary waste stream compositions

- efficacy of a real-time glass oxidation state monitor

- quality and durability of the process's vitreous waste-form product.

During the $120 \mathrm{~h}$ of experimental testing, the processing characteristics of a single melter feed formulation, designated SBW-22, at a fixed $20 \mathrm{wt} \%$ waste loading was evaluated with and without reductant additives. On the basis of laboratory crucible-scale screening tests, the reductants evaluated during melter testing were limited to sugar and glycolic acid. In addition to reductant chemical type, the impacts of varying reductant concentrations upon processing rates, sulfur glass retention, molten-salt accumulations, glass oxidation state $\left[\mathrm{Fe}^{+2}: \mathrm{Fe}^{+3}\right]$, and glass product durability were evaluated.

The melting kinetics of the SBW-22 feed formulation using a sugar reductant was found to be similar to that of the previously evaluated SBW-9 formulation (Goles 2001), but its cold-cap characteristics were somewhat different. Specifically, a much more developed structure was produced by the SBW-22 formulation, which, upon feed interruption, required significantly more time to burn off than was observed for SBW-9. As in previous testing, it was found that sugar feed concentration could be effectively used to control the oxidation state of the melter's product glass. Specifically, RSM-2 data suggest that SBW-22 sugar concentrations as high as $175 \mathrm{~g} / \mathrm{L}-\mathrm{SBW}$ are adequate for maintaining acceptable glass oxidation conditions: $\mathrm{Fe}^{+2}: \mathrm{Fe}_{\text {tot }}<0.3$. Foaming, caused by an inadvertent over-reducing condition, was the only factor that adversely affected processing conditions involving sugar reductant.

The use of glycolic acid reductant with SBW-22 produced a much more developed cold-cap structure than sugar, although it failed as an effective oxidation-state modifier. Due to its ineffectiveness in controlling melter glass oxidation state, relatively high loadings of this reductant were used that further increased cold-cap accumulation and concomitant process-rate reductions. In addition, excessive gas generation at the bottom of the cold cap created glass-foaming conditions that reduced heat-transfer rates and further increased cold-cap accumulations.

Feed was also processed without any reductant modifier during RSM-2 testing. In all cases, inferior processing conditions resulted. Under these strong oxidizing conditions, glass foaming created very significant processing difficulties. In particular, a thick and very persistent insulating foam/cold-cap layer was created that, at the conclusion of an extended campaign, had to be physically broken up and stirred into the bulk glass before subsequent testing conditions could commence. On the basis of the two campaigns conducted, it appears that long-term continuous processing of SBW-22 without a reductant modifier is not a reasonable option.

Beyond controlling glass oxidation state, flowsheet reductants are also used to accelerate feed processing by reducing nitrate to volatile compounds that can be efficiently exhausted from the process. Although the volatile nitrogen oxides produced were directly measured by continuous gas monitors, the degree to which reduction to elemental nitrogen occurs had to be indirectly inferred from process conditions and gas composition data. The results obtained from nitrogen mass balance calculations suggest that on the average, $15 \%$ of the nitrogen fed to the melter during RSM testing was reduced to its elemental state. Furthermore, it appears that the reductive $\mathrm{N}_{2}$ yield is related to reductant concentration. 
Melter glass production rates varied from 6.2 to $9.4 \mathrm{lbs} / \mathrm{h} / \mathrm{ft}^{2}$ for the various feed batches processed. These values comfortably exceed the reference (cold-lid) Liquid Fed Ceramic Melter (LFCM) design production rate of $4 \mathrm{lbs} / \mathrm{h} / \mathrm{ft}^{2}$ that is often quoted and used for flowsheet and equipment sizing estimates (Perez 2001). Indeed, this reference-normalized production rate is exceeded even when projections are based upon the overall average feed rate data $\left(7 \mathrm{lbs} / \mathrm{h} / \mathrm{ft}^{2}\right)$ that are inclusive of all melter idling and batching periods.

Average measured Joule heating power was used with corresponding batch feeding rates, reductant loadings, and heat of combustion information to derive specific process energy requirements for SBW feeds. The average value derived for all batches processed, $4.9 \mathrm{~kW}-\mathrm{h} / \mathrm{kg}$, is slightly greater than typical energy requirements for slurry-fed, Joule-heated ceramic melters ( 2 to $4 \mathrm{~kW}-\mathrm{h} / \mathrm{kg}$ of glass produced) but is significantly less than that derived during previous testing with the SBW-9 formulation. Recognizing that much of the power required in processing slurry feeds is consumed by boiling away water, the higher than average specific-energy requirement for vitrifying SBW-22 noted above is most likely due to the water weight fraction differences.

The partitioning behavior of sulfur was assessed by conducting post-test analysis of all collected process streams. The results of this assessment indicate that $>95 \%$ of the sulfur processed was incorporated within the melter's vitreous product. Indeed, the mass balance results for the overall test suggest that only $\sim 1 \%$ of the sulfur fed to the RSM partitioned to the off-gas system and collected in secondary waste streams. Moreover this mass closure data for sulfur further validates off-gas monitoring and sampling data that did not detect any significant sulfur partitioning as $\mathrm{SO}_{2}$ or $\mathrm{SO}_{3}$. Although process data suggests that higher than average sulfur off-gas partitioning occurred when the highest feed concentrations of sucrose were used, the $\mathrm{SO}_{2}$ presumably produced, is not persistent and is, apparently, quickly oxidized under RSM processing conditions.

Monitoring for molten salt accumulations ( $>90 \%$ alkali $\&$ alkaline sulfates) was conducted throughout all phases of RSM testing. Initial observations after $\sim 15 \mathrm{hrs}$ of processing revealed the presence of small molten salt phase pools on the glass melt surface. Subsequent observations suggested a progressive and continual decline in number and size of observable molten-salt-phase pools. Although never completely absent, the presence of molten salt present at the end of the test was quite difficult to discern.

For the surrogate SBW melter feed used during RSM testing, $\mathrm{CO}_{2}$ and $\mathrm{NO}_{\mathrm{x}}$ (specifically $\mathrm{NO}$ ) were the major non-condensable $\left(\sim 25^{\circ} \mathrm{C}\right)$ gases produced by the vitrification process. The combustible gases $\mathrm{CO}$ and $\mathrm{H}_{2}$ were also detected, but at much lower concentrations: $0.08 \%$ and $0.03 \%$, respectively. These concentrations are well below the lower flammability limits of these combustible gases, $4.65 \%$ for $\mathrm{H}_{2}$ and $15.5 \%$ for CO.

The responses of the total hydrocarbon (THC) analyzer indicated that hydrocarbon compounds with significant room-temperature vapor pressures were present in melter exhaust throughout most periods of testing. Although the off-gas concentrations of these thermal byproducts were relatively low $(<100 \mathrm{ppm}$ on the average), they were, not surprisingly, functionally related to SBW sugar loadings. It also appears that overfeeding and abrupt introduction of feed material into the hot melter are responsible for many of the THC concentration spikes observed during RSM testing. 
Condensed-phase effluents were also monitored during SBW melter testing. The melter's aerosol mass decontamination factors (DFs), as measured by isokinetic filter catches, were determined for each of the distinct feeds processed. These melter aerosol mass DFs, which ranged from 30 to 200, were reflective of the uniquely different processing conditions created by the feeds being processed. The sugar-containing feed stream created the highest off-gas partitioning behavior, while the glycoliccontaining feed produced the lowest. However, cold-cap growth during partitioning measurements may have artificially elevated the aerosol DF associated with the glycolic-containing, feed-processing campaign.

Melter partitioning for individual feed components was also derived from the off-gas sampling and secondary waste-stream data. With the exception of boron, mercury, and the halogens, essentially all feed constituents (excluding $\mathrm{C}, \mathrm{N}, \mathrm{H}_{2} \mathrm{O}$, etc) were found to be primarily in a condensed state downstream of the film cooler. Overall, the element-specific DFs recorded during RSM-2 are reasonably close to general expectations and are generally consistent with previous SBW melter-testing results. However, the cesium DFs recorded during the current test, averaging $\sim 30$, are much more consistent with full-scale expectations than the significantly lower values $(\sim 5)$ recorded during the previous RSM/SBW test.

Of the volatile melter effluents mentioned above (excluding $\mathrm{C}, \mathrm{N}$, and $\mathrm{H}_{2} \mathrm{O}$ ), mercury exhibited the highest volatility and overall loss rates $(\mathrm{DF} \sim 1)$. Only during strongly oxidizing conditions was there evidence $(\sim 5 \%)$ of nonvolatile chemical forms of mercury $(\mathrm{HgO})$ under operating off-gas system temperatures $\left(150^{\circ} \mathrm{C}\right)$. When feed reductant was used, mercury off-gas effluent was primarily ( 90 to $98 \%)$ in the elemental state. Only under oxidizing conditions was there any significant indication (30\%) of other volatile chemically combined forms of mercury being present $\left(\mathrm{HgCl}_{2}\right)$.

The halogens also exhibited high volatility loss rates during the current test. Average DFs $<10$ were recorded for this group of elements. Although only volatile, gas-phase, halogen DFs were measured during this test, it does not appear that aerosol contributions to overall losses would be very significant, given the high volatilities exhibited by these elements.

The evaluation of the secondary waste streams generated during RSM testing revealed significant differences in scrub-solution elemental concentrations when glycolic acid was used as a feed-stream reductant. Specifically, more organic and inorganic carbon effluent was recovered in off-gas waste streams, a higher fraction of captured effluents were collected by the high-efficiency mist eliminator (HEME), and in general there was a lower fraction of undissolved solids (primarily composed of $\mathrm{SiO}_{2}$ and $\mathrm{Fe}_{2} \mathrm{O}_{3}$ ). The halogens as a group comprised the highest percentage of feed elements collected in the scrub solutions. Fluorine was the highest followed by iodine and chlorine. Mercury was the only other element collected in the scrub solution at greater than $10 \%$ of that in the feed.

Representative glass samples generated throughout the duration of RSM-2 testing were subjected to standard durability tests. Specifically, glass samples were subjected to both product consistency test (PCT) (ASTM 1997) and toxicity characteristic leach procedure (TCLP 1992) leach-testing protocols. The PCT results suggest that all RSM-2 glasses were more durable than the standard environmental assessment glass to which they were compared. Furthermore, corresponding TCLP tests indicate that all SBW-22 glasses, even the highly reduced ones, conform to all existing Resource Conservation and Recovery Act (RCRA) land-disposal limits (40 CFR 268). 
A real-time electrochemical method for monitoring glass oxidation state was also evaluated during RSM-2. The results obtained were inconclusive due to the glass dissolution of electrode sheathing material. Proper operation of the reference electrode required controlling localized conditions at the electrode tip. Deterioration of the electrode sheathing material prevented the required control conditions to be sustained over a meaningful evaluation period.

During SBW melter-flowsheet evaluation studies, 90-L of SBW simulated waste having a total mass of $110 \mathrm{~kg}$ were successfully processed by the RSM, producing $22 \mathrm{~L}$ of glass having a total mass of $55 \mathrm{~kg}$. As a result, an overall SBW waste-volume reduction factor of 4.2 was achieved during the current test. This factor is lower than that recorded (7.6) during the previous RSM/SBW melter test because of the significantly lower waste loading used with the SBW-22 formulation during RSM-2 testing.

\section{Reference}

40 CFR 268. Land Disposal Restrictions. Code of Federal Regulations. U.S. Environmental Protection Agency, Washington D.C.

American Society for Testing and Materials (ASTM). 1997. Standard Test Methods for Determining Chemical Durability of Nuclear, Hazardous, and Mixed Waste Glasses: The Product Consistency Test (PCT), ASTM C1285-97, West Conshohoken, PA.

Goles RW, JM Perez, BD MacIsaac, DD Siemer, and JA McCray. 2001. Test Summary Report: INEEL Sodium-Bearing Waste Vitrification Demonstration RSM-01-1, PNNL-13522, Pacific Northwest National Laboratory, Richland, WA.

Perez JM, DF Bickford, DE Day, DS Kim, SL Lambert, SL Marra, DK Peeler, DM Strachan, MB Triplett, JD Vienna, and RS Wittman. 2001. High-Level Waste Melter Study Report, PNNL-13582, Pacific Northwest National Laboratory, Richland, WA.

Toxicity Characteristic Leaching Procedure (TCLP). 1992. Test Methods for Evaluating Solid Waste, Volume 1C: Laboratory Manual Physical/Chemical Methods, SW-846, Method 1311, Rev. 2, U.S. Environmental Protection Agency, Office of Solid Waste and Emergency Response, Washington D.C. 


\title{
Acronyms
}

\author{
AA atomic adsorption \\ APEL Applied Process Engineering Laboratory \\ CEM Continuous Emissions Monitor \\ EA environmental assessment \\ DC direct current \\ DF decontamination factor; ratio of input to output rate \\ DOE U.S. Department of Energy \\ dscm dry standard cubic meter \\ DWPF Defense Waste Processing Facility \\ EPA U.S. Environmental Protection Agency \\ EVS ejector venturi scrubber \\ FY Fiscal Year \\ GC gas chromatograph \\ HEME high-efficiency mist eliminator \\ HEPA high-efficiency particulate air (filter) \\ HLW high-level waste \\ iC inorganic carbon \\ oC organic carbon \\ ICP-AES inductively coupled plasma-atomic emission spectrometer \\ INEL Idaho National Environmental Laboratory \\ INEEL Idaho National Engineering and Environmental Laboratory \\ INTEC Idaho Nuclear Technology and Engineering Center \\ LFCM Liquid Fed Ceramic Melter \\ LOD loss on drying \\ LOI loss on ignition \\ MOG melter off-gas \\ ND not detected/measured or no data available \\ NRTS Nuclear Reactor Testing Station \\ NWCF New Waste Calcining Facility \\ PCT Product Consistency Test
}




$\begin{array}{ll}\text { PLC } & \text { Programmable Logic Controller } \\ \text { PM } & \text { particulate matter } \\ \text { PNNL } & \text { Pacific Northwest National Laboratory } \\ \text { ppm } & \text { parts per million } \\ \text { ppmv } & \text { parts per million by volume } \\ \text { POG } & \text { process off-gas } \\ \text { RCRA } & \text { Resource Conservation and Recovery Act } \\ \text { RPM } & \text { revolutions per minute } \\ \text { REDOX } & \text { reduction oxidation } \\ \text { RSM } & \text { Research-Scale Melter } \\ \text { SBW } & \text { sodium-bearing waste } \\ \text { scfm } & \text { standard cubic feet per minute } \\ \text { SCR } & \text { silicon-controlled rectifier } \\ \text { SEM } & \text { scanning electron microscope } \\ \text { SRTC } & \text { Savannah River Technology Center } \\ \text { STP } & \text { standard temperature and pressure } \\ \text { TCLP } & \text { toxicity characteristic leach procedure } \\ \text { TDS } & \text { total dissolved solids } \\ \text { TFF } & \text { Tank Farm Facility } \\ \text { THC } & \text { total hydrocarbon } \\ \text { TOE } & \text { total operating efficiency } \\ \text { UTS } & \text { Universal Treatment Standard } \\ \text { UV } & \text { ultraviolet } \\ \text { VOC } & \text { volatile organic compound } \\ \text { WCF } & \text { Waste Calcining Facility } \\ \end{array}$




\section{Acknowledgments}

The authors would like to acknowledge the following people:

- Pacific Northwest National Laboratory and Idaho National Engineering and Environmental Laboratory staff who performed laboratory work and Research Scale Melter shift activities

- Wayne Cosby for editorial assistance

- Harry Smith for Technical Review

- E. William Holtzscheiter for management and guidance.

This study was funded by the U.S. Department of Energy's (DOE's) Office of Science and Technology, through the Tanks Focus Area, and the Office of Environmental Management through the Idaho National Environmental and Engineering Laboratory high-level waste program. This study was performed and documented as a collaborative effort by Pacific Northwest National Laboratory (operated for DOE by Battelle under Contract DE-AC06-76RL01830) and the Idaho National Environmental and Engineering Laboratory (operated for DOE by Bechtel, Babcox and Wilcox Incorporated under Contract DE-AC07-94ID 13223). 


\section{Contents}

Abstract ......................................................................................................

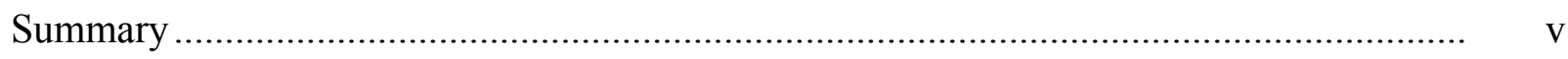

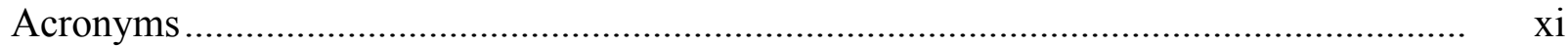

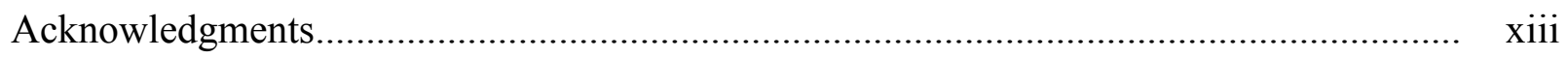

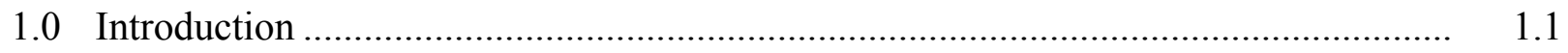

2.0 Test Objectives ................................................................................ 2.1

3.0 RSM System Description ....................................................................

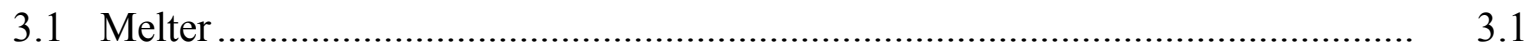

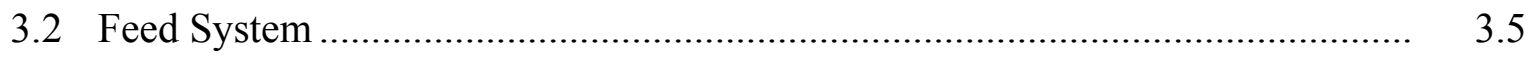

3.3 Off-Gas Processing System....................................................................... 3.8

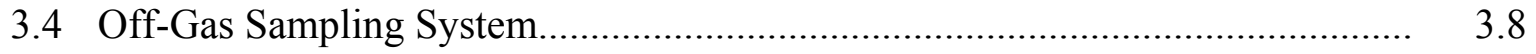

3.5 Data Acquisition and Process Control System ........................................... 3.12

4.0 SBW Simulant, Melter Feed, and Product Glass ............................................. 4.1

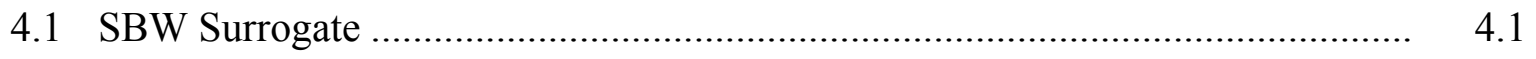

4.2 Target Glass Composition.............................................................................. 4.3

4.3 Glass Former and Chemical Additives ........................................................ 4.3

4.3.1 Glass-Former Rheological Effects .................................................. 4.5

4.3.2 Reductant Additives ..................................................................... 4.6

4.3.3 Reductant Loading .................................................................... 4.7

4.4 Melter Feed Characteristics .................................................................. 4.7

4.5 Product Glass Characteristics................................................................... 4.9

4.5.1 Oxidation-State Evaluations ......................................................... 4.9

4.5.2 Processing and Feed Oxidizing Condition ....................................... 4.15

4.5.3 Compositional Data.................................................................... 4.16

4.5.4 Glass Durability ...................................................................... 4.16

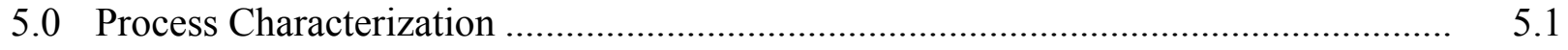

5.1 Processing Observations and Parameters................................................ 5.1

5.2 Operating Parameters .............................................................................. 5.3

5.2.1 Process Temperatures.............................................................. 5.3 


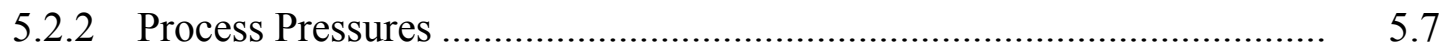

5.2.3 Melter Electrical Data ...................................................................... 5.8

5.2.4 EVS Condensate Tank, Film-Cooler Injection Air .................................. 5.11

6.0 Melter Off-Gas Emission Characterization ................................................................ 6.1

6.1 Gaseous Effluent .................................................................................. 6.1

6.1.1 Total Hydrocarbon Emissions ................................................................... 6.6

6.1.2 Melter Nitrogen Oxide Source Term ..................................................... 6.8

6.1.3 Melter Carbon Oxide Source Term........................................................... 6.10

6.1.4 Mercury Species Concentrations ........................................................... 6.11

6.1.5 Mercury Measurements by the CEM .................................................... 6.12

6.2 Sampling and Total Melter Emission Characterization ..................................... 6.16

6.2.1 Manual Melter Off-Gas Sampling Description....................................... 6.16

6.2.2 Aerosol Mass DFs ......................................................................... 6.17

6.2.3 Aerosol Elemental DFs ................................................................. 6.18

6.2.4 Volatile Partitioning and Total Elemental DFs ...................................... 6.20

6.3 RSM Secondary Waste Streams..................................................................... 6.25

6.3.1 Sampling Schedule and Scrub-Solution Characteristics .......................... 6.26

6.3.2 Analytical Analysis of Scrub-Solution and Collected Solids .................. 6.29

6.3.3 Undissolved Solids: Properties, Composition, Physical Characteristics . 6.36

6.3.4 Melter Feed Constituent DFs ................................................................ 6.41

6.3.5 Summary of Secondary Waste-Stream Findings .................................... 6.43

7.0 Byproducts, Residuals, Mass Balance, and Volume Reduction...................................... 7.1

7.1 Molten-Salt-Phase Composition ...................................................................... 7.1

7.2 Off-Gas Line Deposits ..................................................................................

7.3 Sulfur Processing Characteristics.....................................................................

7.3.1 Process Campaigns, Feed Reductants, and Vitreous Sulfur .................... $\quad 7.5$

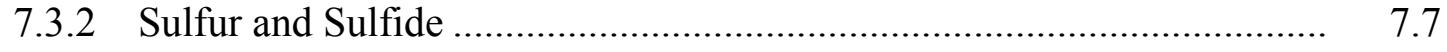

7.4 Process Mass Balance ………………………………….................................. 7.8

7.5 Process Statistics ..................................................................................

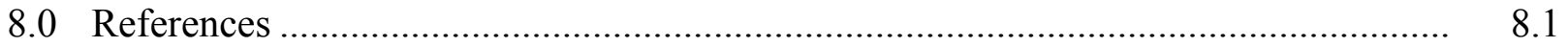


Appendix A: Test Plan for the RSM-01-2 Vitrification Demonstration for INEEL Sodium-Bearing Waste

Appendix B: Test Instruction for Preparing $100 \mathrm{~L}$ of Sodium Bearing Waste Simulant

Appendix C: RSM Feed Batching and Manual Data Sheets

Appendix D: Colorimetric Procedure for Determining $\mathrm{Fe}^{+2}$ to $\mathrm{Fe}_{\text {tot }}$ Ratio

Appendix E: Variable Process-Temperature Data Collected During the SBW Flowsheet Evaluations

Appendix F: Melter Off-Gas Flow Rates (Dry Basis)

Appendix G: Temporal Behavior of Melter Off-Gas Effluents

Appendix H: Photographs of Melter Feed Nozzle Off-Gas Line Deposits and Glass Canisters

Appendix I: Tabular Off-Gas Sampling Data

\section{Figures}

3.1. Photograph of the Research-Scale Melter Demonstration Unit ............................. 3.2

3.2. Schematic of the Research-Scale Melter Processing System ................................ 3.3

3.3. Plan and Elevation View of Temporary Melter Hood Enclosure............................ 3.4

3.4. Exterior View of Melter Enclosure ................................................................ 3.4

3.5. Interior View of Enclosed Melter ............................................................ 3.4

3.6. Cross Section View of the Research-Scale Melter (not drawn to scale) .................. 3.5

3.7. Elevated Feed Tank, Secondary Containment, and Load Cell Platform Scale ......... $\quad 3.7$

3.8. Melter Feed Delivery Valve Station............................................................. 3.7

3.9. Melter Valve Station Configuration and Flow Logic ........................................ 3.8

3.10. Gas Distribution System Supplying Continuous Emission Monitors ..................... 3.10

3.11. Modified EPA Method-5 Sampling Train ...................................................... 3.11

3.12. Sample Train Collection Module ................................................................. 3.11

3.13. Sample Train Flow Control Module................................................................. 3.11

3.14. Melter Off-Gas Line Sampling Port …............................................................ 3.12

4.1. Historical Sugar/Glycolic Feed Concentrations and Glass Oxidation-State Values .. 4.12

5.1. SBW-22 Sugar/Glycolic Concentrations and Feed Processing Rates ..................... 5.3 
5.2. RSM-2 Feed Processing History …………………................................................. 5.4

5.3. RSM-2 Glass Production History .......................................................................... 5.4

5.4. Reductant-Dependent Cold-Cap Burn-Off Characteristics ....................................... 5.8

5.5. Melter Operating and Off-Gas Differential Pressures............................................... 5.9

5.6. RSM Electrode Voltage/Current/Resistance/Power Operating Characteristics ......... 5.9

5.7. RSM-2 Condensate Tank Volume and Film-Cooler Flowrate History ...................... 5.14

6.1. Post Film-Cooler THC and SBW-22 Sugar/Glycolic Concentrations ...................... 6.7

6.2. Time-Resolved, Post Film-Cooler THC and SBW-22 Sugar Concentrations ........... 6.7

6.3. Thermodynamic Prediction of Speciation of Mercury Compounds........................... 6.12

6.4. EVS Solution of Dissolved Solids Accumulation ....................................................... 6.28

6.5. EVS and HEME Solution Acidity ..................................................................... 6.28

6.6. RSM-2 EVS TDS Accumulation Rate — g/h/L ..................................................... 6.30

6.7. Percentage of Elements Scrubbed Found In the HEME Solutions ........................... 6.35

6.8. Proportion of Feed Elements Collected In Scrub Solutions ....................................... 6.35

6.9. Total Scrub Solutions Elemental Accumulation (Higher Values)............................... 6.36

6.10. Total Scrub Solutions Elemental Accumulation (Lower Values) ............................... 6.37

6.11. Comparison of EVS Settled Solids Elemental Composition (Higher Values)........... 6.39

6.12. Comparison of EVS Settled Solids Elemental Composition (Lower Values) ........... 6.41

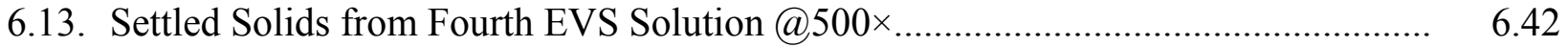

6.14. Settled Solids from 3rd EVS Scrub @ 1000× .............................................................. 6.43

7.1. Melter Off-gas Jumper Configuration and Sample Site Locations ........................... $\quad 7.3$

7.2. Historical SBW-22 Sugar/Glycolic and Glass Sulfur Concentrations ....................... 7.6

\section{Tables}

3.1. RSM Dimensions and Operational Specifications ………………........................... 3.6

3.2. RSM's Continuous Emissions Monitors (CEMs) ………………………………....... 3.9

4.1. INTEC TFF Tank WM-180 Waste and Simulant Compositions ............................... 4.2

4.2. Stable Isotope Chemical Analog Surrogates ……………....................................... 4.3

4.3. SBW and PNNL Surrogate Compositions............................................................... 4.4

4.4. SBW Surrogate Physical Characteristics................................................................... 4.5 
4.5. SBW-22 Target Glass Composition at 20\% Waste Loading...................................... $\quad 4.5$

4.6. Melter Feed Glass-Former Additives and Equivalent Frit Composition..................... 4.5

4.7. Physical Properties of Surrogate SBW Melter Feeds .................................................. 4.8

4.8. Melter Feed Composition for Batch Samples RSM-01-2-XYZ .................................. 4.9

4.9. SBW Reductant Type and Loadings vs. Glass Oxidation State ................................ 4.11

4.10. Results of Various Ways of Characterizing the Redox States of RSM-2 Glasses ..... 4.14

4.11. Oxide Composition of Vitrified SBW-22 Feed Formulation ..................................... 4.17

4.12. Comparative Oxide Composition of SBW-22 Glass.................................................. 4.18

4.13. PCT Leachate Results from SBW-22 Glasses............................................................. 4.20

4.14. TCLP Leachate Concentrations from SBW-22 Glasses............................................ 4.21

5.1. RSM-2 Slurry Feeding Rates and Calculated Glass Production Rates* ................... 5.2

5.2. Melter and Off-Gas System Operating-Temperature Characteristics ....................... 5.6

5.3. Melter Kiln, Pour Spout, and Canister Oven Temperatures...................................... 5.7

5.4. RSM Electrode Circuit Operating Characteristics...................................................... 5.11

5.5. Specific Process Energy Requirements for SBW-22 Feeds ........................................ $\quad 5.12$

5.6. Operational Characteristics of Melter Kiln and Overflow Heaters ............................ 5.13

6.1. Unquenched, Post Film-Cooler, Melter Off-Gas Composition, and Flow Rate

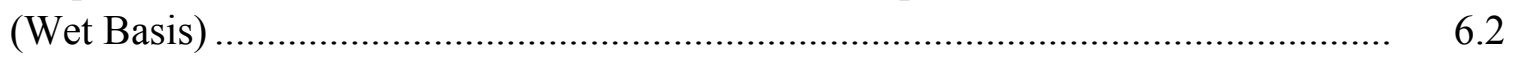

6.2. Projected Melter Effluent Concentrations and Flow Before Film Cooler Dilution ... 6.4

6.3. Campaign-Dependent Nitrogen Oxide Mass Balance Data ........................................ 6.9

6.4. Campaign-Dependent Carbon Oxide Mass-Balance Data ………………………...... $\quad 6.10$

6.5. CEM Mercury Measurements .......................................................................... 6.14

6.6. Comparison of CEM and EPA Metals Train Mercury Measurements in Melter

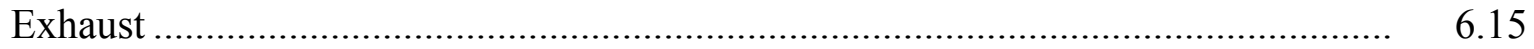

6.7. Gross, Post Film-Cooler Melter Aerosol Emission Characteristics ……………........ 6.18

6.8. Normalized Composition of Melter-Generated Aerosols and Melter Feed ............... 6.19

6.9. Elemental Melter DFs Associated with Aerosol Emissions ....................................... 6.21

6.10. Volatile Melter DFs for Halogen and Sulfur Feed Constituents .............................. 6.22

6.11. Particulate Loss Percentages of Melter Effluents........................................................ 6.23

6.12. Distribution of Mercury Effluents Across -0060 Sample Train Components............ 6.23

6.13. Total Individual Elemental Melter DF Values ……………………………................ 6.25 
6.14. Processing Campaigns Monitored by Secondary Waste Streams Studies

6.15. RSM-2 Scrub Solutions Soluble Elemental Constituents (Values in Grams Collected per Liter of SBW Fed).

6.16. Settled Solids Information

6.17. EVS Settled Solids Elemental Composition (Values in Grams per Liter SBW Fed)

6.18. SEM Semi-Quantitative Results of First Scrub Very Fine Suspended Settled Solids

6.19. Waste Stream-Derived, Campaign-Dependent Melter DFs

7.1. Composition of Dissolved Molten Salt Samples*

7.2. Assumed Chemical Forms and Weight Contributions of Salt Constituents

7.3. Unnormalized Off-Gas Deposit Compositions

7.4. Total Sulfur and Sulfide Content of SBW-22 Glasses By Wet Chemical Methods... 